УДК 811.111:81’37]:[659.126:687.553]

DOI https://doi.org/10.26661/2414-1135-2021-82-13

\title{
СТРУКТУРНО-СЕМАНТИЧНІ ОСОБЛИВОСТІ КОЛЬОРОПОЗНАЧЕННЬ В АНГЛІЙСЬКІЙ МОВІ (НА МАТЕРІАЛІ СУЧАСНИХ БРЕНДІВ ДЕКОРАТИВНОЇ КОСМЕТИКИ)
}

\author{
Залужна О. 0. \\ кандидат філологічних наук, \\ завідувач кафедри англійської філології \\ Донецький національний університет імені Василя Стуса \\ вул. 600-річчя, 21, Вінниия, Україна \\ orcid.org/0000-0002-7929-6769 \\ olgazaluzhna@gmail.com \\ Астахова О. C. \\ студентка кафедри англійської філології \\ факультету іноземних мов \\ Донецький національний університет імені Василя Стуса \\ вул. 600-річчя, 21, Вінниия, Украӥна \\ orcid.org/0000-0001-7272-6220 \\ astakhova_o@donnu.edu.ua
}

\begin{abstract}
Ключові слова: колір, кольоропозначення, семантика, структура, структурна модель, семантична мотивація, англійська мова, лінгвокультура.
\end{abstract}

Стаття присвячена дослідженню семантики та структури кольоропозначень на матеріалі англомовних номінацій кольорів помад, тіней, рум'ян, хайлайтерів, бронзерів та лаків для нігтів, використовуваних у 2010-х і на початку 2020-х років сучасними британськими та американськими брендами декоративної косметики, які були отримані методом суцільної вибірки 3 офіційних Інтернет-ресурсів брендів (629 кольоропозначень (лексем та словосполучень)). Актуальність вибраної теми наукової розвідки зумовлена, передусім, динамічністю цієї системи в сучасних висококонкурентних умовах ринку косметичної продукції, що призводить до пошуку нових вимірів номінації кольорів та їхніх відтінків у цій галузі.

Встановлено, що колір із-поміж інших ознак предмета використовується як його відмінна риса, розпізнавальна особливість зорового сприйняття світу людиною і передає значення двома основними способами: природними асоціаціями та психологічними, або культурними, символами.

Аналіз емпіричного корпусу дослідження підтверджує тенденцію до переосмислення традиційних стандартів утворення кольороназв для привернення уваги споживачів та більш привабливого іміджу продукції на ринку. Вищеокреслена тенденція призводить до того, що точність передачі назви кольору, його відтінку або тону відходить на периферію, а емоційно-психологічна складова частина, залучена до процесу номінації, набуває найбільшої значущості. Кількісний аналіз корпусу дослідження демонструє, що високою продуктивністю відрізняються кольоропозначення досліджуваних брендів декоративної косметики, які генетично пов'язані з іменниками на позначення тварин, рослин, природних явищ; меншою продуктивністю характеризуються кольоропозначення із семантикою казкових створінь, найменування елементів сонячної системи, географічні назви, власні імена, сучасний сленг, іменники на позначення напоїв та продуктів харчування. Структурно домінують однокомпонентні моделі «іменник» та «прикметник», і двокомпонентні моделі «прикметник + іменник» та «іменник + іменник». Однокомпонентні структурні моделі «числівник» та «вигук»; двокомпонентні моделі «дієслово + прислівник», «прикметник + прикметник», «дієслово + займенник» тощо визначаються низькою продуктивністю. 


\title{
STRUCTURAL AND SEMANTIC PECULIARITIES OF COLOR NOMINATIONS IN THE ENGLISH LANGUAGE (BASED ON MODERN BRANDS OF MAKE-UP COSMETICS)
}

\author{
Zaluzhna O. O. \\ PhD in Philology, \\ Head of English Philology Department \\ Vasyl'Stus Donetsk National University \\ 600-richya str., 21, Vinnytsia, Ukraine \\ orcid.org/0000-0002-7929-6769 \\ olgazaluzhna@gmail.com
}

Astahova O. S.

Student at the Faculty of Foreign Languages

Vasyl'Stus Donetsk National University

600-richya str., 21, Vinnytsia, Ukraine

orcid.org/0000-0001-7272-6220

astakhova_o@donnu.edu.ua

Key words: color, color nomination, semantics, structure, structural model, semantic motivation, the English language, linguoculture.
The article is devoted to the study of units denoting color, i.e., their semantics and structure and is based on the material of the English language units nominating colors and their shades for lipsticks, eyeshadows, blushes, highlighters, bronzers, and nail polishes used by British and American brands in 2010s and the beginning of 2020s. The material was obtained by continuous sampling method from official websites of the brands (629 units, both lexemes and word-combinations). The topicality of the present research is mainly predetermined by dynamic character of the color nominations system in modern highly competitive make-up market environment which leads to the search of new dimensions for color nominations. The research allows to arrive at conclusion that color characteristics, among other features of the object, functions as its distinctive feature defined by the peculiarity of human visual perception of the world, transmitting information through two major channels: natural associations and psychological or cultural symbols.

The empiric database analysis confirms the overall tendency to rethinking traditional standards of color nominations to attract the customers' attention and create a more appealing image of the products on the market. The above tendency leads to the fact that the accuracy of the color transmission (including its shades) shifts to the periphery, moving to the center emotional and psychological components involved to the nomination process.

Quantitative analysis demonstrates that highly productive semantics models are nominations coined from names of animals, plants, and nature phenomena; less productive are color nominations related to magical creatures, solar system objects, geographical names, proper names, modern slang, nouns denoting drinks and food. Structural dominance is manifested by mono-component models 'noun' and 'adjective', and double-component models 'adjective + noun' and 'noun + noun'. Mono-component models 'numeral' and 'interjection'; double-component models 'verb + adverb', 'adjective + adjective', 'verb + pronoun', etc. are characterized by low productivity. 
Вступ. У мовознавстві традиційним $є$ підхід до вивчення лексичних систем кольоропозначень 3 огляду на те, що, з одного боку, номінації базових кольорів слугують основою для виникнення в мові нових найменувань відтінків (напр. англ. blue -> navy blue, baby blue, royal blue і т.д.), з іншого - базою для утворення нових кольоропозначень можуть виступати назви різних предметів та явищ як із повсякденного життя, так і зі світу природи (напр. fuchsia, manve, turquoise, mustard і т.д.).

Явище кольоропозначення повсякчас знаходиться під пильною увагою лінгвістів та мовознавців. Оскільки кольоропозначення фігурують як важлива частка мовної концептуалізації світу, володіють ємною семантичною структурою та стильовою активністю, вчені у своїх працях розглядають проблеми їх існування, вплив на мозок і психічний стан людини, символічне значення кольорів тощо. Встановивши національні домінанти кольоропозначень, можна вирішити питання, пов'язані з різнобічним явищем діалогу культур $[1$, с. 9]. Втім, попри множинні публікації останніх років, які свідчать про пильну увагу до цього явища $[1 ; 2 ; 5$; $6 ; 8 ; 10 ; 12]$, ця динамічна галузь лексики потребує більш детального опрацювання.

Актуальність представленої теми дослідження полягає в потребі детально вивчити структурно-семантичні особливості сучасних кольоропозначень в англійській мові для подальшої можливості укладення типології відбиття цілісної картини світу іiї носіїв початку XXI ст. Зацікавленість вибраною темою також зумовлена необхідністю дослідити механізми впливу кольоропозначень на споживачів продукції декоративної косметики сучасних косметичних брендів.

Мета полягає в дослідженні структурно-семантичних особливостей кольоропозначень в англійській мові на матеріалі сучасних британських (Avon, Makeup Revolution) та американських (Jeffree Star Cosmetics, Anastasia Beverly Hills, Haus Laboratories, Rare Beauty, Fenty Beauty, Kylie Cosmetics) брендів декоративної косметики.

Об'єктом дослідження є одиниці (слова та словосполучення) на позначення кольорів (кольоропозначення) в англійській мові, які використовують світові бренди декоративної косметики у період 2010-х та початку 2020-х років.

Предметом $\epsilon$ структурно-семантичні особливості кольоропозначень у сучасній англійській мові.

Матеріалом дослідження слугують 629 кольоропозначень (відтінків помад, тіней, рум'ян, хайлайтерів, бронзерів та лаків для нігтів) в англійській мові, які були отримані методом суцільної вибірки з Інтернет-ресурсів офіційних представників брендів декоративної косметики.

Теоретичні засади дослідження. У широкому колі праць, пов'язаних із питанням кольоропо- значення, спостерігається певна неоднорідність стандартизації терміна на позначення одиниці дослідження: кольороназва, назва кольору, кольоропозначення, колірний термін, ім'я кольору, кольоронайменування, колірний прикметник, кольоратив, колірний епітет тощо. У цій науковій розвідці за робоче прийняте таке визначення: кольоропозначення - відкрита система, яка визначається історичною сталістю, має різнобічну словотвірну структуру лексем та ємну семантичну структуру, зумовлену багаторічним розвитком [7, с. 14].

Наукову розвідку англійських вчених Б. Берліна та П. Кея «Basic Colour Terms: Their Universality and Evolution» [10] нині вважаємо однією з найгрунтовніших із позиції аналізу кольоропозначень: у ній науковці ставлять за мету визначення кола кольорів, які можна зарахувати до базових, та ідентифікацію загальних правил розподілу цих кольорів у близько вісімдесяти мовах. Намагаючись спростувати ідеї, закладені в працях Е. Сепіра та Б. Уорфа [11], які висувають гіпотезу, що сприйняття та мислення загалом напряму залежать від рідної мови людини, Б. Берлін і П. Кей доходять висновків, що 1) 95\% кольорів походять від назв предметів, 2) лише $5 \%$ слів не мають чіткої етимології, 3) колір є семантичною універсалією, 4) базовий колірний термін виступає як основна одиниця кольоропозначень (англ. basic colour term), 5) їхня кількість вважається обмеженою, 6) колір характеризується ознаками відтінку (англ. hue), яскравості (англ. brightness) та насиченості (англ. saturation) [10, с. 25]. Учені також виокремлюють 11 основних кольорів, які знаходяться у відповідній ієрархії: англ. black 'чорний' - yellow 'жовтий' - pink 'рожевий' - red 'червоний' - blue 'синій' - brown 'коричневий' - orange 'помаранчевий' - white 'білий' - green 'зелений' grey 'сірий' - purple 'фіолетовий'.

Необхідно зазначити, що семантика кольоропозначень безпосередньо вмотивована предметом, який використовується для ознаки кольору, а завдяки значному впливу різноманітних факторів (психологічного, фізіологічного, культурного) зміна емоційного та експресивного значення, метафоричного переосмислення та метонімічного переносу постійно розбудовується та ускладнюється. Встановлено, що колір із-поміж інших ознак предмета використовується як його відмінна риса, розпізнавальна особливість зорового сприйняття світу людиною, тому опанування семантики слова пов'язане з особистісним розумінням смислової ознаки предмета. Розгорнений опис семантики кольоропозначень неможливий без з'ясування початкового семантичного елемента, що підтверджує необхідність вивчення походження кольорового символу, його змісту, синтезу явищ та подій життя людей для розуміння 
сучасних теорій концептуального вивчення кольоропозначень [3, с. 190].

Ф. Біррен вважає, що синонімія слугує початком семантичних змін кольоронайменувань, а сам процес відзначається трьома етапами: «співіснування» (англ. coextention) назв; «включення» (англ. inclusion), яке дозволяє набути власні значення або їхні відтінки; «доповнення» (англ. complementation) [9, с. 89]. Основними джерелами для подальшого утворення кольоропозначень також є полісемія, запозичення та лексеми на позначення відтінків. У своїй розвідці Ф. Біррен також представляє власну систематизацію - раціональне кольорове коло, яке об'єднує 13 кольорів (жовтий, жовтувато-зелений, зеленувато зелений, зелений, бірюзовий, синій, фіолетовий, червоно-фіолетовий, червоний, червоно-помаранчевий, помаранчевий, помаранчево-червоний) навколо сірого, який самостійно не $є$ центральним. Представлена система виділяє більше місця для «теплих» кольорів (між червоним і жовтим), ніж для «холодних» (між зеленим та фіолетовим), що підтверджує здатність людського ока розрізняти теплі кольори виразніше та слугує поясненням їх домінантного місця в мистецтві.

За потрактуванням Т.Ф. Семашко, основне лексичне значення лексем кольоративів 3'ясовується шляхом зіставлення із семами тих слів, 3 якими лексико-семантичний варіант утворює парадигматичні ряди [7, с. 15]. Найпоширенішим способом реалізації цих сем $є$ модель словосполучення із семантичною структурою «ознака - предмет» або «прикметник - іменник»: absolute coral 'чистий корал', hot plum 'розпечена слива', French toast 'французький тост', vibrant melon 'енергійна диня’. Семантика кольоропозначення базується на виборі основного компонента, який своєю чергою може відображати не тільки конкретну ознаку, але й конотативну [27, с. 15-16].

Говорячи про структуру лексико-семантичної групи кольоропозначень, прийнято виокремлювати дві основні складові частини [7]. Це - центр, або ядро, яке включає в себе найбільш уживані архісеми, та майже необмежена периферія. Аналіз, проведений А.В. Кудріною та Б.Г. Мещєряковою, демонструє, що ядром зеленого кольору в українськомовній культурі слугують природа та рослинність, а периферією є молодість, надія, дозвіл і свобода дій. В англомовній культурі ядро залишиться незмінним, а периферія набуває нового значення: рух із захисту навколишнього середовища (партія «зелених»), заздрість, ревнощі, гроші, символ Ірландії. Цей поділ дає змогу послідовно визначити семантичну будову кольоропозначень ахроматичних (чорний, білий, сірий), хроматичних (червоний, помаранчевий, жовтий, зелений, голубий, синій, фіолетовий) кольорів та кольоропозначень-прикметників, які формують периферію навколо основного значення [5, с. 171].

Проблема символізму кольору та пов'язані 3 нею питання $є$ важливими аспектами в дослідженні кольоропозначень. Колір передає значення двома основними способами - природними асоціаціями та психологічними, або культурними, символами. Наприклад, вважається, що відтінки синього викликають асоціації з небом і психологічне усвідомлення спокою та вдоволення. Взаємозв’язок кольору з такими явищами викликає відчуття комфорту, i через це за кольором чи кольоропозначенням закріплюється відповідний образ [6, с. 352]. На відміну від природних асоціацій, які є спільними для більшості людей, існує й символіка, яка походить від культурного і сучасного контексту та не є універсальною.

Результати дослідження. Аналіз семантичних особливостей кольоропозначень у брендах сучасної декоративної косметики є цінним джерелом для дослідження функціонування кольоролексики загалом. 3 огляду на динамічний розвиток сфери декоративної косметики в сучасному світі та вагому функцію кольоропозначень як єдиних прикметних символів недиференційованих предметів, потреба аналізу номінації кольору та його похідних значно примножується. Маркетингова назва, яка приверне увагу покупців, не завдяки точності передачі назви кольору, відтінку, його тону, але радше завдяки емоційно-психологічній складовій, залученій до процесу номінації, стає найбільш значущою. Споживачі продукції будьякої галузі промисловості дедалі більше не просто сприймають кольоровий спектр, але й активніше реагують, як наслідок, більш охоче купують таку продукцію. Саме вищезазначеними факторами можна пояснити появу таких кольоропозначень, запропонованих сучасними брендами декоративної косметики, наприклад, Unicorn Blood 'кров єдиноріга', Sultry 'пристрасний', Sworn Enemy 'заклятий ворог', Insomniac 'той, хто страждає від безсоння', Rum Punch 'ромовий пунш', Mulled Wine 'глінтвейн'.

У пропонованій науковій розвідці було визначено, що високою продуктивністю відрізняються кольоропозначення досліджуваних брендів декоративної косметики, які позначають тварин (Pretty Panther 'гарненька пантера', Flamingo 'фламінго'), рослини (Carnation 'гвоздика', Hibiscus 'гібіскус'), природні явища (Lava 'лава'). Меншою продуктивністю характеризуються кольоропозначення iз семантикою казкових створінь (Unicorn 'єдиноріг', Griffin 'грифон'), найменування елементів сонячної системи (Mars 'Марс'), географічні назви (Hollywood 'Голлівуд', Savannah 'Саванна'), власні імена (Ariel 'Аріель'), сучасний сленг (Trippin 'галюцинувати', Ridiiic ‘сміховинний’), 
іменники на позначення напоїв (Cherry Soda 'вишнева содова', Sangria 'сангрія', Mocha 'мокко') та продуктів харчування (Cupcake 'кекс', Peaches 'персики', Cheesecake 'чізкейк').

Специфічні риси в семантиці кольоропозначень можна пояснити особливостями виникнення асоціативного ряду в синтезі з відповідним кольором та відмінностями в поєднанні кольорових компонентів в англійській мові. Це зумовлено динамічним розвитком та осучасненням брендів через номінації, які вони використовують. Суспільні інституції та особливості норм поведінки щороку невпинно змінюються та впливають на лексико-семантичне наповнення кольоропозначень. Денотативне значення семантичної структури кольоронайменування згасає i на перший план виходять конотативні компоненти [4, с. 68].

Для аналізу структурних особливостей кольоропозначень брендів сучасної декоративної косметики за основу було взято потрактування Т.Ф. Семашко реалізації зіставлення лексем кольоративів із семами слів, з якими лексико-семантичний ряд утворює парадигматичні ряди, у відповідних структурних моделях словосполучення [7, с. 15]. У процесі дослідження було ідентифіковано 18 структурних моделей на позначення кольору.

Найпоширенішим способом реалізації сем кольоративів визначено модель із монокомпонентною структурою «іменник», яку було зафіксовано 309 разів, що становить 49\% від загальної кількості досліджуваних кольоропозначень, наприклад, Pumpkin 'гарбуз', Phobia 'фобія', Revenge 'помста', Lemonade 'лимонад', Nostalgia 'ностальгія', Ink 'чорнило'. Стисло і чітко викладена конструкція дає змогу мислити в динамічному та емоційному аспекті. Оскільки торгівельні операції досліджуваних косметичних компаній здійснюються для великої кількості країн усього світу, раціональним є використання яскравого, помітного, односкладного найменування, яке легко запам'ятати за допомогою побудови асоціативного ряду в людському психофізіологічному механізмі формування відчуттів кольору. Саме таку функцію і виконує модель «іменник».

Другою за продуктивністю $є$ двокомпонентна модель «прикметник + іменник» (100 одиниць, $16 \%$ від загального корпусу дослідження), наприклад, Blue Lagoon 'блакитна лагуна', Free Woman 'вільна жінка', Wild Child 'дике дитя', Black Forest 'чорний ліс', Perfect Illusion 'ідеальна ілюзія'. Висока частотність також притаманна монокомпонентній моделі найменування кольору «прикметник» (78 одиниць, що становить 12\% емпіричного корпусу дослідження), наприклад, Botanical 'ботанічний', Untamed 'неприборканий’, Royal 'королівський', Ruby 'рубіновий’ та двокомпонентній моделі «іменник + іменник» (64 кольоропозначення (11\% корпусу дослідження)), наприклад, Angel Tears 'сльози ангела', Trust Issues 'питання довіри', Cookie Dough 'тісто для печива', Flamingo acid 'кислотний фламінго'. При цьому іменник у складі словосполучення може позначати різноманітні об'єкти на позначення кольору (предмети, процеси, природні явища, історичні події, тварини, рослини, цінні метали, власні імена, географічні назви тощо).

Хоча структурні моделі «числівник» (6 одиниць, наприклад, 911, 1950, Twenty One 'двадцять один'), «вигук» (4 одиниці, наприклад, Воо, Yaaas!, Bang Bang, Ouch); двокомпонентні моделі «дієслово + прислівник» (Running Late, Talk Dirty), «прикметник + прикметник» (Cool Brown), «дієслово + займенник» (Fire Me) тощо і визначаються низькою продуктивністю, їхнє залучення до процесу кольоронайменування сучасними брендами косметичної продукції підтверджує тенденцію до переосмислення традиційних стандартів утворення кольороназв для привернення уваги споживачів та більш привабливого іміджу продукції на ринку.

Висновки. Система кольоропозначень кожної мови як відбиття цілісної картини світу зумовлена багатьма факторами: соціокультурними, психологічними, історичними, суспільно-політичними, які у своїй сукупності визначають цінності, які характеризують ту чи іншу лінгвокультуру.

Семантика кольоропозначень $\epsilon$ динамічною системою через наявність у мові як прямих, так і переносних, символічних значень кольору, які утворюються в результаті соціокультурних змін та переосмислення їхнього емоційного та експресивного значення.

Високою продуктивністю відрізняються кольоропозначення досліджуваних брендів декоративної косметики, які семантично вмотивовані іменниками на позначення тварин, рослин, природних явищ; меншою продуктивністю характеризуються кольоропозначення із семантикою казкових створінь, найменування елементів сонячної системи, географічні назв, власні імена, одиниці сучасного сленгу, іменники на позначення напоїв та продуктів харчування.

Найпоширенішим способом реалізації структурної моделі є однокомпонентна модель «іменник» (309 лексем, 49\%), двокомпонентна модель «прикметник + іменник» (100 одиниць, 16\%), однокомпонентна модель «прикметник» (78 лексем, $12 \%$ ) та двокомпонентна модель «іменник + іменник» (64 одиниці, 11\%). Однокомпонентні структурні моделі «числівник» та «вигук»; двокомпонентні моделі «дієслово + прислівник», «прикметник + прикметник», «дієслово + займенник» тощо визначаються низькою продуктивністю. 
Перспектива подальшого дослідження полягає в розширенні емпіричного корпусу дослідження для укладення типології відбиття кольоро-картини світу носіями англомовної лінгвокультури. Ще одним вектором подальшого розвитку вважаємо мультимодальний підхід до вивчення кольоропозначень у галузі номінації кольорів декоративної косметики з урахуванням комплексу маркетингових чинників їх укладання та функціонування.

\section{ЛІТЕРАТУРА}

1. Голованевська К.П. Англійські фразеологізми-колороніми та їх відтворення в українському перекладі. Запоріжжя : Запорізький національний технічний університет, 2018. $180 \mathrm{c}$.

2. Деева И.М. Валентные свойства английских прилагательных - «периферийных» цветообозначений. Теоретические вопросы английской филологии (Лексикология). Горький, 1974. C. $164-180$.

3. Іншаков А.Є. Теоретичні засади дослідження колірної лексики в мовознавстві. Філологічні студіi. Науковий вісник Криворізького державного педагогічного університету. 2013. Вип. 9. С. 188-195.

4. Ковальська І.В. Особливості відтворення стилістичної семантики колірних лексем у перекладі (на матеріалі української та англійської мов). Мовознавство. 1999. № 4-5. С. 67-70.

5. Кудрина А.В., Мещеряков Б.Г. Семантика цвета в разных культурах. Психологический журнал Международного университета природы, общества и человека «Дубна». 2011. С. 1-18.

6. Месяц С.В. Иоганн Вольфганг Гёте и его учение о цвете (часть первая). Москва : Кругъ, 2012. 464 c.

7. Семашко Т.Ф. Семантична структура лексичних одиниць на позначення кольору в українській мові. Мовознавство. 2009. Вип. 17. C. 14-21.

8. Berlin B., Kay P. Basic Colour Terms: Their Universality and Evolution. Berkley and Los Angeles, California: University of California Press, 1969. 178 p.

9. Birren F. Color Psychology and Color Therapy: A Factual Study of The Influence of Color on Human Life. N.Y.: Putnam press, 1961. 312 p.

10. Kay P., Berlin B., Maffi L., Merrifield W. R., Cook R. The World Color Survey. Stanford CA: CSLI Publications Stanford University, 2009. P. 21-56.

11. Worf B. L. The Phonetic Value of Certain Characters in Maya Writing. Cambridge: Harvard University, 1933. P. 91-96.

12. Wierzbicka, A. There are no "Color Universals" but There are Universals of Visual Semantics. Anthropological Linguistics, 47(2). 2005. P. 217-244.

\section{REFERENCES}

1. Holovanevska, K.P. (2018). Anhliiski frazeolohizmy-koloronimy ta yikh vidtvorennia $v$ ukrainskomu perekladi [English Phraseonyms-coloronyms and Their Reflection in Ukrainian Translation]. Zaporizhzhia: Zaporizkyi natsionalnyi tekhnichnyi universytet. $180 \mathrm{p}$.

2. Deeva, I.M. (1974). Valentnyie svoystva angliyskih prilagatelnyh - "periferiynyh" tsvetooboznacheniy [Valency Properties of English Adjectives - "Periphery" Color Nominatoins]. Teoreticheskie voprosy angliyskoy filologii (Leksikologiya). Gorkiy. Pp. 164-180.

3. Inshakov, A.Ye. (2013). Teoretychni zasady doslidzhennia kolirnoi leksyky v movoznavstvi [Theoretical Foundations of Color Vocabulary Research in Linguistics]. Filolohichni studii. Naukovyi visnyk Kryvorizkoho derzhavnoho pedahohichnoho universytetu. Issue 9, pp. 188-195.

4. Kovalska, I.V. (1999). Osoblyvosti vidtvorennia stylistychnoi semantyky kolirnykh leksem u perekladi (na materiali ukrainskoi ta anhliiskoi mov) [Peculiarities of Stylistic Semantics Reflection of Color Lexemes in Translation (on the Material of the Ukrainian and English Languages)]. Movoznavstvo. № 4-5. Pp. 67-70.

5. Kudrina, A V., \& Mescheryakov, B.G. (2011). Semantika tsveta $\mathrm{v}$ raznyh kulturah [Semantics of Color in Different Cultures]. Psihologicheskiy zhurnal Mezhdunarodnogo universiteta prirody, obschestva i cheloveka «Dubna». Pp. 1-18.

6. Mesyats, S.V. (2012). Iogann Volfgang Gyote $i$ ego uchenie o tsvete (chast pervaya) [Johann Wolfgang Goethe and his Theory about Color (Part One)]. M. : Krug. 464 p.

7. Semashko, T.F. (2009). Semantychna struktura leksychnykh odynyts na poznachennia kolioru v ukrainskii movi [Semantic Structure of Lexical Units Denoting Color in the Ukrainian Language]. Movoznavstvo. Issue 17. Pp. 14-21.

8. Berlin, B., \& Kay, P. (1969). Basic Colour Terms: Their Universality and Evolution. Berkley and Los Angeles, California: University of California Press. 178 p.

9. Birren, F. (1961). Color Psychology and Color Therapy: A Factual Study of The Influence of Color on Human Life. N.Y. : Putnam press. 312 p.

10. Kay, P., \& Berlin, B., \& Maffi, L., \& Merrifield, W. R., \& Cook, R. The World Color Survey. Stanford CA : CSLI Publications Stanford University. Pp. 21-56.

11. Worf, B.L. (1933). The Phonetic Value of Certain Characters in Maya Writing. Cambridge : Harvard University. Pp. 91-96.

12. Wierzbicka, A. (2005). There are no "Color Universals" but There are Universals of Visual Semantics. Anthropological Linguistics. 47(2). Pp. 217-244. Retrieved April 9, 2021. URL: http://www.jstor.org/stable/25132327 